\title{
In situ measurements
}

(U-Pb, Lu$\mathrm{Hf}$, trace elements) in zircons to unravel the record of magmatic evolution within a Cretaceous ABTS belt

\section{Other Conference Item}

\section{Author(s):}

von Quadt, Albrecht; Peytcheva, Irena; Heinrich, Christoph A. (D)

Publication date:

2006-08

\section{Permanent link:}

https://doi.org/10.3929/ethz-b-000035868

\section{Rights / license:}

Creative Commons Attribution-NonCommercial-NoDerivatives 4.0 International

\section{Originally published in:}

Geochimica et Cosmochimica Acta 70(18 / Supplement), https://doi.org/10.1016/j.gca.2006.06.1263 


\title{
In situ measurements $(\mathrm{U}-\mathrm{Pb}, \mathrm{Lu}-\mathrm{Hf}$, trace elements) in zircons to unravel the record of magmatic evolution within a Cretaceous ABTS belt
}

\author{
A. von Quadt ${ }^{1}$, I. Peytcheva ${ }^{1,2}$, C.A. Heinrich ${ }^{1}$ \\ ${ }^{1}$ IGMR, ETH-Zurich, 8092 Zurich, Switzerland (vonquadt@, \\ erdw.ethz.ch; heinrich@erdw.ethz.ch) \\ ${ }^{2}$ CLMC-Bulgarian Academy of Sciences, Sofia, Bulgaria
}

The development of improved techniques for the in situ $\mathrm{U}-\mathrm{Pb}$ and $\mathrm{Lu}-\mathrm{Hf}$ isotope analysis and trace element contents has revolutionized approaches to modelling the origin and evolution of magmas and the petrogenesis of granites. The key point is to obtain representative samples that preserve "record" of the processes and it has been accepted that is best provided by zircons. In magmatic rocks, zircons saturate from the primary magma, but may be also inherited from host magmatic or metamorphic rocks with mantle or continental crust origin. For our case studies, we selected intrusive and extrusive magmatic rocks with gabroic to granitic composition from the Central Srednogorie zone of the Cretaceous Apuseni-Banat-Timok-Srednogorie belt. Based on conventional $\mathrm{U}-\mathrm{Pb}$ single zircon grain dating a magmatic age migration from north to south $(92.1-78.8 \mathrm{Ma})$ is obtained, whereas $\mathrm{Sr}, \mathrm{Pb}$ and $\mathrm{Nd}$ analyses on $\mathrm{WR}$ samples indicate a decreasing crustal input into mantle derived magmas.

In situ LA-ICP-MS trace elements distribution of zircons is useful to distinguish between newly saturated and inherited grains/cores, whereas the concentration of more then 30 trace elements have been determined for zircons from a wide range of rock types. Generally REE patterns in magmatic zircons change insignificant, but the hybrid gabbro zircons reveal the highest abundances of REE, U and Th. Some characteristic geochemical signatures of zircon from different rock types are recognized in bivariate discriminant diagrams.

In situ LAM-MC-ICPMS Hf isotopic ratios are routinely measured with sub-epsilon unit precision. Yb interfering-correction for the zircon measurements is made by standard zircon material including adding of $\mathrm{Yb}$ solutions. $\varepsilon$ - $\mathrm{Hf}$ of the magmatic zircons range between +7 and +11 and a typical ${ }^{176} \mathrm{Lu} /{ }^{177} \mathrm{Hf}$ ratios for zircons of $0.0009-0.0064$ is measured. Detrital parts within grains with lead inheritance shift the $\varepsilon$-Hf data to negative values.

The in situ microanalytical data help here to illustrate the complexity of magma genesis processes in a subduction-roll back scenario. The application of detailed studies of crystal growth history, integrated with high-resolution trace-element and isotopic analysis, can provide new insights into magmatic processes.

\section{Reference}

von Quadt, A., Moritz, R., Peytcheva, I., Heinrich, C.A., 2005. Ore Geol. Rev. 27, 95-126. 